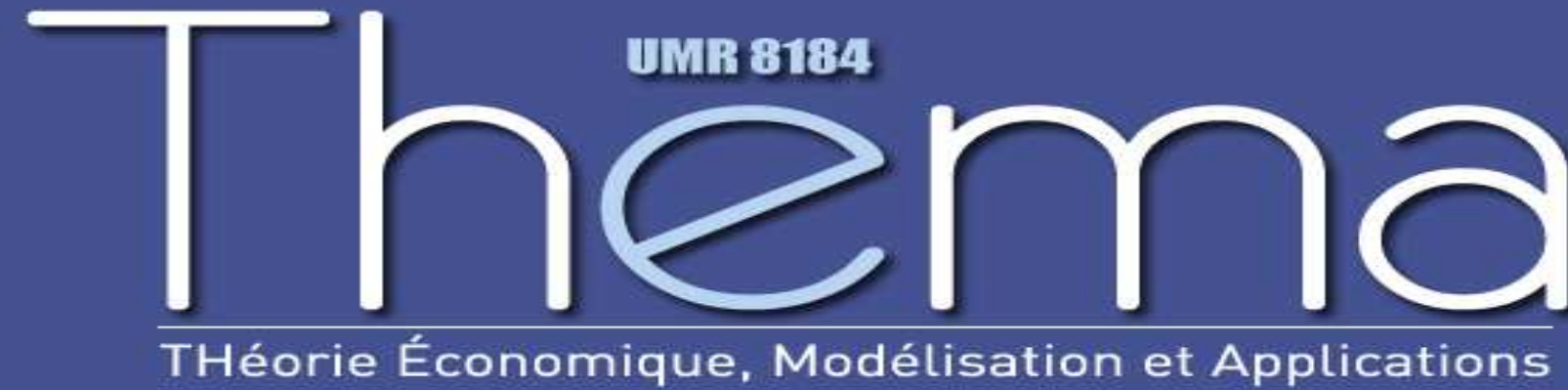

THEMA Working Paper n²015-09 Université de Cergy-Pontoise, France

\title{
Development and the labor share
}

Paul Maarek and Elsa Orgiazzi

Septembre 2015 


\title{
Development and the labor share
}

\author{
Paul Maarek*and Elsa Orgiazzi ${ }^{\dagger}$
}

September 8, 2015

Abstract We highlight a U-shaped relationship between development and the labor share of income. We exploit the "within dimension" of a panel dataset for the labor share in the manufacturing sectors of developing countries. Data is also available at the disaggregated level for 28 manufacturing subsectors. We show that the U-shaped pattern of the labor share is also observed at the subsector level suggesting that it does not correspond to reallocation forces across sectors during the development process. We show that standard theories of development economics that feature duality on the labor market generate such a pattern. At earlier stages of development, productivity gains are not compensated by wage increases as most of the workforce's outside opportunities remain in the traditional sector where firms' productivity is low. At later stages, the labor share increases as the result of wage competition in the modern, high productivity sector.

Keywords: Development ; The labor share ; Dual labor market

J.E.L classification: E25;J42 ; O17

\footnotetext{
*Université de Cergy-Pontoise and THEMA. e-mail: Paul.Maarek@u-cergy.fr

†Université de Rennes I and CREM. e-mail: Elsa.Orgiazzi@univ-rennes1.fr
} 


\section{Introduction}

There is a vast literature, both theoretical and empirical, linking income inequality to economic development starting with Kuznets [25] and examining a potential inverted U-shaped pattern of inequality along the development path. In this paper, we adopt an original perspective concerning this debate by focusing on the labor share of income, that is the ratio of wage bill to value-added. The example of China is illustrative. Since the beginning of the economic boom, wages evolution was far from capturing the spectacular productivity boom, which has reinforced competitivity in the industry. Conversely during the last few years, wages increased substantially more than productivity. For example, according to the Chinese National Bureau of Statistics, Chinese private sector wages rose by $14 \%$ in 2012 as the result of the increase in the tightness of the labor market. We show that this pattern may be inherent to the development process and that it is not specific to the China case. We use panel data with total wage bill and value added available at the manufacturing sector level (hereafter "aggregate level") and also for the 28 subsectors of the manufacturing. We show that the labor share follows a U-shaped relationship at the aggregate level and also within the 28 manufacturing subsectors. This suggests that the wedge between productivity and wages which is observed at the aggregate level is not the result of composition effects that occur during the development process.

We then rationalize our empirical findings. We introduce an simple model to illustrate our stylized fact. It is now established that dualism in the organization of production activities is pervasive in developing countries (DCs) where traditional, low-productivity methods of production coexist with modern, higher-productivity methods. This is at the heart of many models in development economics (see Banerjee and Newman [4] for instance) where agents doing occupational choice face constraints to enter the modern, high productivity sector. We show that it is quite natural for the labor share to exhibit such a U-shaped pattern in those classes of model characterized by firm heterogeneity.

Traditionally, economists have devoted much attention to the pattern of personal income inequality despite the recent interest in the issue of factor income distribution. We see at least two reasons why focusing on the labor share of income along the development path is important. First, if wage increases do not compensate productivity gains, this could affect competitivity and net exports. Second, development is often seen as a necessary condition for the well-being of people. But we also know since Kuznets [25] that the first stage of development may be associated with an increase in inequality. In this paper we focus on the factor distribution of income which is a key 
component of personal income inequality since capital distribution is more concentrated than wage distribution. ${ }^{1}$ Most of the papers in the literature on inequality have focused on wage or income inequality but little attention has been paid to factor income distribution. The main reason for the neglect of the labor share relies on Kaldor's stylized fact [22] in favor of constant labor shares across time and space, in spite of Solow's [38] skepticism. This fact - mainly inspired from the US experience - is not supported by recent empirical studies. Not only the labor share sharply decreased in many European countries since the 1980's, but it also decreased in developing countries and more particularly in less developed countries (see Decreuse and Maarek [13] or Harrison [20]). In addition, the labor share remains substantially higher in developed countries than in developing ones (see Ortega and Rodriguez [30] for instance). More recently, the labor share also decreased in the US since the mid 2000's (see Rodriguez and Jayadev [36] or Karabarbounis and Neiman $[23])$.

This article offers several contributions. First it exploits the panel dimension of the labor share for developing countries at the aggregate level and at the sectoral level. We mainly use a specific dataset from UNIDO, a subdivision of the UN, which allows us to have reliable data on the labor share for developing countries at the disaggregate level and to study the long run evolution within countrie and within sectors. To our knowledge, we are the first to exploit such a dataset in order to study the long run impact of development on the labor share, which is not possible with other datasets on the labor share (see below). We identify a clear U-shaped pattern of the labor share at the aggregate level and also at a more disaggregate level. Second, data allows us to discriminate between several potential causes affecting the labor share that are generally identified in the literature. The fact the U-shaped pattern is observed at the aggregate level but also within the 28 manufacturing sub-sectors suggests that this U-shaped pattern is not related to the structural changes that occur during the development process and which could affect the aggregate labor share through a simple composition effect. Moreover since we control for factor accumulation that may impact the labor share and since it does not affect our U-shaped relationship between development and the labor share, we argue that it is very likely that the Ushaped pattern of the labor share origins in the wage determination process during development. This is not a controversial idea in the development economic literature featuring dual labor market. For instance, Lewis [26] argues that labor supply is unlimited in the modern sector of the economy

\footnotetext{
${ }^{1}$ Checchi and García Peñalosa [10] show that the labor share is an important determinant of personal income inequality in OECD countries. Similarly, García Peñalosa and Orgiazzi [16] highlight the increasing role of unequal possession of capital in some industrialized countries. Concerning developing countries, Daudey and García Peñalosa [12] show that a larger labor share is associated with a lower Gini coefficient of personal incomes and that the effect is quantitatively large.
} 
where firms have a much higher productivity than in the traditional one, generating relatively low wages with respect to productivity in this sector. We formalize this argument using the seminal framework of Banerjee and Newman [4] in the simplest version of Ghatak and Jiang [17]. We only focus on the static part of the model since we are not interested in explaining the development process but its consequences in terms of the labor share. In this model, in order to enter the modern sector of the economy and benefit from the modern technology, an individual has to pay a fixed capital cost. There is an initial wealth distribution in the economy and the credit market is imperfect so a proportion of the agents in the economy is credit constrained. As in the Banerjee and Newman [4] framework, capital accumulation implies a modification in the proportion of credit constrained agents. We also consider an increase in the productivity of modern firms compared to traditional ones. We show that such a framework generates a U-shaped relationship between development and the labor share under plausible assumptions. The intuition is the following: when the proportion of modern firms is insufficient to absorb labor supply, wages remain stuck at low level reflecting the low productivity in the traditional sector. As the proportion of modern firm expends (or their productivity increases), value added in the economy increases but since wages remain low, the labor share decreases. This "Lewis effect" implies that the labor share decreases at first stages of development. Once the proportion of credit constraint agents is sufficiently low, the proportion of modern firms is sufficiently high to absorb the labor supply and wages jump to a higher level. The labor share increases as a result generating our U-shaped relationship. Actually we argue that any workhorse model of development economics exhibiting a duality on the labor market can generate this U-shaped relationship.

This paper relates to different strands of literature. First, it belongs to the growing literature on the labor share, as emphasized by the contributions of Bentolila and Saint Paul [7], Blanchard and Giavazzi [8], Acemoglu and Guerrieri [2], Maarek and Orgiazzi [28], Bazillier and Najman [6], Decreuse and Maarek [13], Rodrik [37] or Karabarbounis and Neiman [23] or Piketty [31]. None of these papers focus on the role of the economic development in developing countries. However a notable exception is Gollin [18] who argues that after correcting the labor share data for selfemployment income, the link between the labor share and development disappears. We argue that using more suitable data for the labor share in developing countries -data allowing time comparisons- yields to a strong correlation between development and the labor share. Indeed, by correcting the labor share for self-employment income, Gollin is only able to compare the labor shares for a dozen of developing economies at one point in time. Our data on the manufacturing 
sector does not require such a correction since self-employed are excluded from the sample by the UNIDO (see below).

Second, the paper is related to the literature on inequality along the development path. This literature started with Kuznets [25], who argues that inequality increases during the first stages of development as population shifts from the agricultural sector (where income is more equally distributed) to the urban sector (where it is less equally distributed). During later stages of development, this force is more than offset by the fact that within the urban sector income becomes more equally distributed. This idea has been formalized later on by Robinson [35], Knight [24], and Fields [15] who argued that the rural-urban income differential is constant and equally distributed, but that the share of the population in the agricultural sector changes with development, producing the familiar inverted U-shape for evolution of income inequality over time. Nevertheless, Bourguignon and Morrisson [9] review the empirical evidence of such an inverted U-shaped relationship and show that it is not robust. This paper adopts a quite different perspective by focusing on the labor share which is one possible component of personal income inequality but not the only one. As explained later, we mainly focus on the labor share in the manufacturing sector and as a result, this work relies more on a within-sector analysis. Furthermore, we argue that it is not surprising to find such a pattern in the data when thinking of the impact of development in dual labor market models.

\section{Empirical evidence}

\subsection{Empirical strategy}

Our empirical analysis consists in estimating a reduced form equation on sectoral panel data. The dependent variable is the labor share and our regressor of interest is the GDP level which captures the level of development. In order to allow for a non monotonic relationship between development and the labor share we use two different approaches focusing firstly on aggregate data at the level of the manufacturing sector and then at the subsector level.

On the one hand we estimate the relationship between development and the labor share on developing countries only, allowing for a non linear relationship between the two by including in our regression the squared GDP: 


$$
\begin{aligned}
L S_{i t}= & a+a_{i}+a_{t} \\
& +\beta_{1} G D P_{t-1}+\beta_{1} G D P_{t-1}^{2}+\beta_{3} I / Y_{i t-1}+\beta_{4} O P E N T_{i t-1} \\
& +\beta_{5} \text { OPENK }_{i t-1}+\beta_{6} \text { School }_{i t-1}+\varepsilon_{i t}
\end{aligned}
$$

where $a_{i}$ and $a_{t}$ are respectively country fixed effects and time dummies. We control for factor accumulation, trade and financial openness as well as the level of education since they are the main determinants of the labor share identified by the literature (see below). All independent variables are lagged in order to control for potential endogeneity problems which are likely to arise when examining the labor share. Using fixed effects we control for unobserved heterogeneity over time and across countries.

On the other hand we estimate linearly this relation on aggregate manufacturing data for four income classes of countries: low income countries (LIC), lower-middle countries (LMC), uppermiddle countries (UMC) and high income countries (HIC). ${ }^{2}$ The estimated model is the following:

$$
\begin{aligned}
L S_{i t}= & a+a_{i}+a_{t} \\
& +\beta_{1} G D P_{t-1}+\beta_{2} I / Y_{i t-1}+\beta_{3} \text { OPENT } T_{i t-1}+\beta_{4} \text { OPENK } K_{i t-1} \\
& +\varepsilon_{i t} .
\end{aligned}
$$

Note that in these linear estimations the level of education is not added as a control variable since it significantly reduces the number of observations without appearing to be significant in the results of the model specified in equation 1 . This is particularly problematic for the low income economies where the number of observations is particularly low.

Since we focus on the effect of development on the labor share we have to take into account that development is very likely to modify the productive structure of the economy. Indeed, development is an unbalanced process where some sectors develop whereas others shrink as claimed by Kuznets [25] and many others. Indeed, it is common to observe that development is paired with an increase of the industrial and the service sectors and a decrease of the agricultural one. This can be either due to demand effects (such as non homothetic preferences) or to supply effects. Since there is no reason why these effects should not also be at play within the manufacturing sector, we have

\footnotetext{
${ }^{2}$ In order to separate countries according to their level of development we use the classification of the World Bank whose criterion is simply the Gross National Income per capita in 2006.
} 
to wonder if the observed change in the labor share reflects structural effects or changes in the sharing of the value added within sectors.

For that, let's recall that the labor share in a country $i$ at time $t$ is the sum of the sectoral labor shares $L S_{i, t, s}$ weighted by the sectoral shares $\phi_{i, t, s} \equiv y_{i, t, s} / y_{i, t}$, that is:

$$
L S_{i, t}=\sum_{s=1}^{n} \phi_{i, t, s} L S_{i, t, s}
$$

We can decompose the aggregate variation of the labor share between time $t$ and time $t-1$ into a within term and a composition term as follows:

$$
\Delta L S_{i t}=\sum_{s=1}^{n}\left(L S_{i, t, s}-L S_{i, t-1, s}\right) \phi_{i, t-1, s}+\sum_{s=1}^{n}\left(\begin{array}{c}
\left.\phi_{i, t, s}-\phi_{i, t-1, s}\right) L S_{i, t, s} \\
\text { composition effect }
\end{array}\right.
$$

where the operator $\Delta$ stands for the first order difference operator between $t$ and $t-1$.

Two terms appear. The first one represents the within effect and equals the sum of the variations of the labor share within each sector, weighted by the initial sector share. This corresponds to the "real variation" of the labor share. The second term corresponds to what we call the "composition effect" and equals the variation of the share of each sector in the economy, weighted by the final value of the labor share. This term captures the extent to which the variation in the aggregate labor share is due to changes in the structure of the manufacturing sector.

We are interested in the within effect that development has on the labor share since we want to see how the process of sharing the value added is impacted by development. Therefore we perform estimations on sectoral data controlling for crossed fixed effects : country*sector fixed effects allow us to capture the within variation of the labor share and sector*year fixed effects for symmetric shocks that would occur in some specific sectors. As a robustness check we also control for country, time and sector fixed effects separately and provide results in the appendix.

The estimated model is :

$$
\begin{aligned}
L S_{i t s}= & a+a_{i s}+a_{t s} \\
& +\beta_{1} G D P_{i, t-1}+\beta_{2} G D P_{i, t-1}^{2}+\beta_{3} I / Y_{i, t-1, s} \\
& +\beta_{4} O P E N T_{i, t-1}+\beta_{5} O P E N K_{i, t-1}+\beta_{6} \text { School }_{i, t-1}+\varepsilon_{i t s}
\end{aligned}
$$


where $a_{i s}$ is a country*sector fixed effect and $a_{t s}$ is a year*sector fixed effect. ${ }^{3}$ Adding a dummy for every sector in each country allows us to control for potential modifications of the structure of the economy since we control for individual heterogeneity. Doing so we perform within estimations since we observe deviations of the labor share from the mean within the individual dimension. Therefore the coefficients $\beta_{1}$ and $\beta_{2}$ reflect the effect of total output on the labor share within subsectors.

Finally, another way to eliminate the effect that development may have on the structure of the manufacturing sector -which in turn is likely to impact the level of the labor share- we perform estimations on each subsector separately and provide the results in the appendix.

\subsection{Data}

We compute the labor share from UNIDO data. This data covers 180 countries over the period 1963-2003. ${ }^{4}$ The UNIDO data provides various variables at the aggregate manufacturing level, as well as at the 3 digit level for 28 subsectors. ${ }^{5}$

The labor share is defined as the ratio of wages and salaries over value added. ${ }^{6}$ As argued by Gollin [18] this definition implies that all the income of the self-employed is treated as capital income which underestimates the labor share. This is particularly problematic in our study because it could bias the impact of development. Indeed, during development the share of population being self-employed declines which mechanically implies that the overall wage bill increases. Therefore using data where the value added contains self-employment income and defining the labor share naively as the ratio of the wage bill over value added is likely to lead us to mistakenly interpret an increase in the labor share as a change in the "real" sharing of value added. On the contrary data from UNIDO allows us to avoid this problem. Indeed, the surveys sent by UNIDO are designed to collect data only in the corporate manufacturing sector specifying a cut-off point below which economic activity is not measured. ${ }^{7}$ Consequently this selection removes to a large extent the

\footnotetext{
${ }^{3}$ Note that due to a lack of data for developing countries, the only sectoral explanatory variable we dispose of is investment over value added $(I / Y)$ which is a proxy for capital intensity.

${ }^{4}$ The UNIDO data mainly comes from industrial surveys which are sent by UNIDO to the country statistical offices. The version of the UNIDO data that we use is INDSTAT 2005 ISIC Rev.2

${ }^{5}$ The subsectors in the UNIDO data are: Food products; Beverage; Tobacco; Textile; Wearing apparel, except footwear; Leather products; Footwear, except rubber or plastic; Wood Products; Furniture, except metal; Paper and products; Printing and publishing; Industrial chemicals; Other chemical; Petroleum refineries; Misc. petroleum and coal products; Rubber products; Plastic products; Pottery, china, earthenware; Glass and products; Other non-metallic mineral products; Iron and steel; Non ferrous metal; Fabricated metal products; Machinery, except electrical; Machinery, electric; Transport equipment; Professional and scientific equipment; Other manufactured products.

${ }^{6}$ See Appendix for a more precise definition of these variables.

${ }^{7}$ The cutoff can change between countries. For example, in developing countries, firms with less than five employees are not covered. In the US, the requirement is that establishments must have at least one paid employee.
} 
problem of self-employment.

We could have chosen to use as the main dataset one including the self-employed like the UN data, and adjust the labor share for self-employment income as suggested by Gollin [18] in a seminal contribution. However, there would have been major problems. First, self-employment income is available for very few developing countries as detailed by Trapp [39]. Second, the availability is restricted to very few years, which does not allow for time comparisons, see Trapp [39]. For instance, Gollin is able to correct the naive definition of the labor share by taking into account self-employment income for only 12 developing countries at one time point only. Third, there are several competing methods to correct for self-employment income, which are not totally satisfying, which lead to different measures (sometimes aberrant) and which accentuates the variance of the labor share. Finally, UNIDO data is available at a disaggregate level for a larger panel of developing countries, and for a longer period than any other data on developing countries. Of course our approach has major drawbacks. First we examine the effect of development on the manufacturing sector only, and not on the whole economy. Second, self-employment represents a large share of the population in the developing world that we do not observe. Nevertheless, as stressed above, using another database including self-employment income would have forced us to correct the naive definition of the labor share which is, once again, at best prone to measurement inconsistencies, at worst not possible for many countries and not possible in order to have a time dimension.

Another problem with the UN National Accounts Data is that it includes the non profit sector whose value added is often computed by considering that it corresponds to labor costs, inducing a labor share of $100 \%$ for such activities. Once again, as these activities expend during the development process, it implies an increase in the labor share which does not reflect the forces behind the sharing of the value added. Of course we could substract this sector from the overall value added but this would imply a very sharp decreasing of the already low availability of these UN data.

In conclusion, this is in our mind the only dataset which has a sufficient time coverage for developing countries to allow us to observe variations of the labor share at the sectoral level. For example, in the UN dataset it is not possible to perform estimations of the model described in equation 2 on the two lowest income groups of countries because of lack of data, even at the aggregate level.

Note that one of the problems that we have been faced with UNIDO data is that the way in 
which the manufacturing sector is disaggregated in subsectors can change over time and countries. For instance in Bolivia in 1981 the manufacturing sector is disaggregated in 28 subsectors whereas it is only disaggregated in 27 subsectors in 1979 and in 26 in 1976. Hence, for each country we retain only years with the same sectoral structure and we choose the sectoral structure covering the maximum number of observations. Doing this protects us from mistakenly interpreting a change in the labor share within sectors as the reflect of a change in the way the manufacturing sector is disaggregated in the data.

The UNIDO data consists of a panel dataset of almost one hundred countries where the labor share of the whole manufacturing sector is available at least once, around $60 \%$ of them being developing countries.

We include a number of control variables suggested by the previous literature. First we control for capital accumulation since it is the only determinant of the labor share when factors are paid their marginal product. Doing so allows us to test for the capital-accumulation channel of development in the case of a non-Cobb-Douglas function. Indeed, if the elasticity between labor and capital is different from one, capital or human capital accumulation changes the level of the labor share even in a competitive context. For that we use the ratio of gross fixed capital formation to value added as a proxy for capital-output ratio. In some regressions we also add an education variable to control for human capital accumulation all the more so as there is empirical evidence of a positive link between education and the labor share, at least for OECD countries, see Daudey and Decreuse [12]. We use as a proxy of human capital the average schooling years in the total population aged 25 and more (see Barro and Lee [5]).

The second kind of control variables we use, namely trade and financial openness, are related to globalization. As mentioned above, various studies have shown that those variables are negatively correlated to the labor share, see Rodrik [37], Harrison [20], Jayadev [21], Ortega and Rodriguez [29] and Guscina [19]. Therefore, omitting openness variables would potentially create endogeneity problems since openness may be related to development. We use as a proxy for trade openness the ratio of import plus export to GDP for the whole economy from the World Bank available from 1960 to 2006 for more than 200 countries. To measure financial openness we use the de jure index of Chinn and Ito [11] which captures how policies are restrictive toward capital flows. It is a continuous composite index available from 1960 to 2006 for more than 200 countries. 


\subsection{Econometric analysis}

Our first specification, equation (1) regresses the labor share on the level of GDP and on its square for developing countries. It is first estimated at the aggregate manufacturing level using UNIDO data and results are reported in table 1.

Table 1: Aggregated data on the manufacturing sector

\begin{tabular}{|c|c|c|c|c|c|c|}
\hline \multicolumn{7}{|c|}{ UNIDO data } \\
\hline$G D P$ & $\begin{array}{l}38.87^{* * *} \\
(12.08)\end{array}$ & $\begin{array}{l}-108.59^{* * *} \\
(22.00)\end{array}$ & $\begin{array}{l}134.53^{* *} \\
(56.75)\end{array}$ & $\begin{array}{l}-98.44^{* *} \\
(39.42)\end{array}$ & $\begin{array}{l}-119.32^{* * *} \\
(44.57)\end{array}$ & $\begin{array}{l}-129.45^{* *} \\
(48.89)\end{array}$ \\
\hline$G D P^{2}$ & $\begin{array}{l}2.55^{* * * *} \\
(0.78)\end{array}$ & $\begin{array}{l}6.95^{* * *} \\
(1.38)\end{array}$ & $\begin{array}{l}8.41^{* *} \\
(3.62)\end{array}$ & $\begin{array}{l}6.35^{* *} \\
(2.49)\end{array}$ & $\begin{array}{l}7.60^{* * *} \\
(2.84)\end{array}$ & $\begin{array}{l}8.18^{* *} \\
(3.10)\end{array}$ \\
\hline$I / Y$ & & & $\begin{array}{l}0.43 \\
(2.47)\end{array}$ & $\begin{array}{l}0.87 \\
(4.18)\end{array}$ & $\begin{array}{l}2.12 \\
(2.38)\end{array}$ & $\begin{array}{l}2.43 \\
(3.05)\end{array}$ \\
\hline$O P E N T$ & & & $\begin{array}{l}-0.03 \\
(0.05)\end{array}$ & $\begin{array}{l}0.09^{* *} \\
(0.04)\end{array}$ & $\begin{array}{l}-0.04 \\
(0.05)\end{array}$ & $\begin{array}{l}-0.04 \\
(0.06)\end{array}$ \\
\hline$O P E N K$ & & & $\begin{array}{l}0.66 \\
(0.79)\end{array}$ & $\begin{array}{l}-1.38 \\
(0.97)\end{array}$ & $\begin{array}{l}1.28 \\
(0.82)\end{array}$ & $\begin{array}{l}1.26 \\
(0.85)\end{array}$ \\
\hline School & & & $\begin{array}{l}-4.16^{* * *} \\
(1.47)\end{array}$ & $\begin{array}{l}-1.28 \\
(1.14)\end{array}$ & & $\begin{array}{l}0.38 \\
(1.62)\end{array}$ \\
\hline Country FE & No & Yes & Yes & No & Yes & Yes \\
\hline Time FE & No & Yes & No & Yes & Yes & Yes \\
\hline R-squared & 0.02 & 0.77 & 0.73 & 0.24 & 0.77 & 0.76 \\
\hline $\mathrm{Nb}$ of Obs. & 688 & 688 & 624 & 624 & 688 & 624 \\
\hline
\end{tabular}

Whichever the specification of the model presented in equation (1), we can see that both the coefficient of GDP and of its square are significant, the former being negative and the latter being positive. This suggests a U-shaped relationship between development and the labor share.

Figure 1 plots this relationship: the vertical axis is $L S_{i t}-\widehat{a_{i}}-\widehat{a_{t}}-\widehat{\beta} X_{i t(s)}$ where $\widehat{a_{i}}, \widehat{a_{t}}$ and $\widehat{\beta}$ are the estimated coefficients presented in the fifth column of table $1, X_{i t(s)}$ stands for a vector of control variables presented in equation (1) ; the horizontal axis is the logarithm of $G D P_{i t}$. We can observe that the relationship is not only non-monotonous but also U-shaped and that there are a lot of observations in the decreasing part of the curve as well as in the increasing part. The turning point above which development has a positive impact on the labor share is around $2600 \$$ per capita. ${ }^{8}$ We also check necessary and sufficient conditions for a U-shaped relationship using the test proposed by Lind and Melhum [27]. Finally, we show in the appendix (see figure 2) that although being weaker, the partial correlation between GDP and the labor share is still visible when the vertical axis is the labor share net only of country fixed effects : $L S_{i t}-\widehat{a_{i}}$.

We also perform estimations of the model presented in equation (2) regressing the labor share

\footnotetext{
${ }^{8} \mathrm{GDP}$ is measured in PPP at constant prices of year 2007.
} 


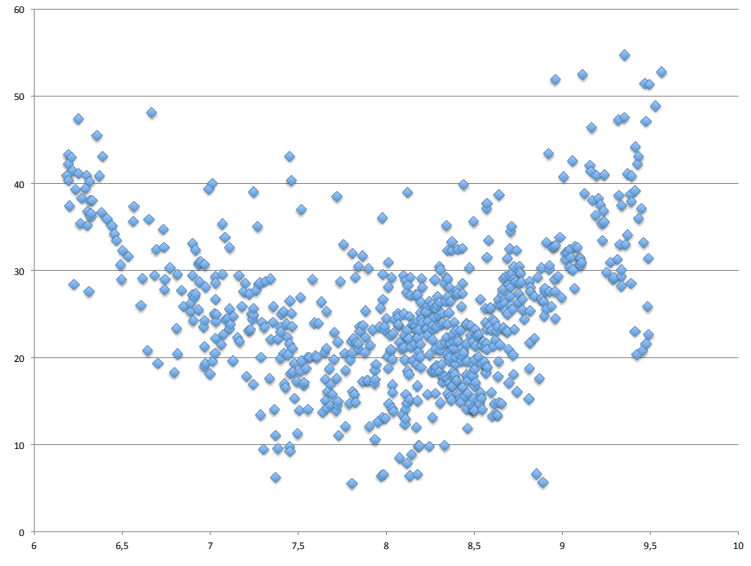

Figure 1: Development and the labor share: the Kuznets hypothesis

on the level of GDP only, for different classes of income at the aggregate manufacturing sector level.

Results presented in table 2 (LI, LMI, UMI and HI) show that development has a significant and negative impact on the labor share for low income economies whereas it significantly increases the labor share in upper-middle economies. That means that development has a negative impact on the labor share at very early stages and then a positive one when the economy develops. Results also suggest that development has no impact for most advanced economies.

Table 2: Development and the labor share : aggregated data

\begin{tabular}{ccccc}
\hline & & & & UNIDO data \\
\hline & LI & LMI & UMI & HI \\
$G D P$ & $-15.87^{* *}$ & -2.15 & $23.06^{* *}$ & 5.99 \\
& $(6.23)$ & $(4.96)$ & $(10.48)$ & $(5.15)$ \\
$I / Y$ & $3.74^{* * *}$ & 1.17 & 5.93 & $26.12^{* * *}$ \\
& $(1.01)$ & $(2.76)$ & $(10.93)$ & $(5.70)$ \\
OPENT & $-0.25^{* * *}$ & 0.02 & -0.03 & $-0.27^{* *}$ \\
& $(0.06)$ & $(0.09)$ & $(0.07)$ & $(0.10)$ \\
OPENK & $3.34^{* * *}$ & 1.95 & -0.65 & 0.04 \\
& $(1.07)$ & $(1.45)$ & $(0.96)$ & $(0.75)$ \\
\hline \hline Country FE & Yes & Yes & Yes & Yes \\
Time FE & Yes & Yes & Yes & Yes \\
R-squared & 0.83 & 0.75 & 0.84 & 0.75 \\
Nb of Obs. & 164 & 320 & 204 & 460 \\
\hline
\end{tabular}

Clustered standard errors in brackets

$$
p<0.10,{ }^{* *} p<0.05,{ }^{* * *} p<0.01
$$

We next turn to estimations on sectoral data (i.e., the 28 manufacturing subsectors) and estimate the model described by equation (3). Once again we regress the labor share on GDP 
and its square to see the impact of development on the sharing of the value added. As explained in subsection 2.1, controlling for country*sector fixed effects allows us to control for individual heterogeneity and so to clean the effect that structural changes may have on the labor share when the economy develops. Doing so we only rely on the within sector variations of the labor share to estimate the coefficients of interest. Results are reported in table 3.

Table 3: Development and the labor share: sectoral data on developing countries

\begin{tabular}{|c|c|c|c|c|c|}
\hline & $(1)$ & $\overline{(2)}$ & $\overline{(3)}$ & $(4)$ & $\overline{(5)}$ \\
\hline$G D P$ & $\begin{array}{l}-89.764^{* *} \\
(38.268)\end{array}$ & $\begin{array}{l}-89.782^{* *} \\
(38.265)\end{array}$ & $\begin{array}{l}-91.596^{* *} \\
(38.264)\end{array}$ & $\begin{array}{l}-111.602^{* * *} \\
(38.486)\end{array}$ & $\begin{array}{l}-111.341^{* * *} \\
(39.849)\end{array}$ \\
\hline$G D P^{2}$ & $\begin{array}{l}5.801^{* * *} \\
(2.246)\end{array}$ & $\begin{array}{l}5.802^{* * *} \\
(2.246)\end{array}$ & $\begin{array}{l}6.004^{* * *} \\
(2.289)\end{array}$ & $\begin{array}{l}7.112^{* * *} \\
(2.299)\end{array}$ & $\begin{array}{l}7.096^{* * *} \\
(2.365)\end{array}$ \\
\hline$I Y$ & & $\begin{array}{l}-0.003 \\
(0.002)\end{array}$ & $\begin{array}{l}-0.003 \\
(0.002)\end{array}$ & $\begin{array}{l}-0.002 \\
(0.002)\end{array}$ & $\begin{array}{l}-0.002 \\
(0.002)\end{array}$ \\
\hline OPENT & & & $\begin{array}{l}-0.058 \\
(0.072)\end{array}$ & $\begin{array}{l}-0.040 \\
(0.074)\end{array}$ & $\begin{array}{l}-0.040 \\
(0.079)\end{array}$ \\
\hline$O P E N K$ & & & & $\begin{array}{l}2.558^{* * *} \\
(0.741)\end{array}$ & $\begin{array}{l}2.556^{* * *} \\
(0.745)\end{array}$ \\
\hline School & & & & & $\begin{array}{l}0.099 \\
(1.563)\end{array}$ \\
\hline Country x Sector FE & Yes & Yes & Yes & Yes & Yes \\
\hline Time $\mathrm{x}$ Sector FE & Yes & Yes & Yes & Yes & Yes \\
\hline R-squared & 0.301 & 0.301 & 0.303 & 0.303 & 0.303 \\
\hline $\mathrm{Nb}$ of Obs. & 11968 & 11968 & 11845 & 11845 & 11845 \\
\hline
\end{tabular}

We can derive several lessons from those regressions. First, the coefficients of GDP and of $G D P^{2}$ are significantly negative and significantly positive respectively, confirming our previous results. Second, since we control for country*sector fixed effects, we observe a within effect which means that the reason why development impacts the labor share is not due to composition effects. Third we observe that adding our control variables increases the size of the effect of development. That means that the effect that development has on the labor share is not due to factor accumulation, as the neoclassical theory suggests, nor to openness which is one of the best candidate to the observed decline/changes of the labor share in the literature. Moreover the effect that development has on the labor share is even stronger when controlling for openness.

Note that the coefficient on capital intensity is equal to zero and not significant which suggests that empirical evidence on the link between capital accumulation and the labor share captures the effect of development per se and that the channel of capital accumulation is not valid. Concerning education, the coefficient is positive but not significant. Financial openness has a sign which is not 
in line with the studies of Harrison [20] and Jayadev [21]. Lastly, trade openness has the expected negative sign although not significant.

Now we turn to the 28 regressions performed on each subsectors. Results are presented in tables A2, A3, A4, A5 and A6 in the appendix. Twenty four subsectors exhibit a U-shaped relationship between GDP and the labor share although not always significant. This is due to the fact that the number of observations drops when focusing on the subsectors separately and that UNIDO data appears more noisy at the sector level than at the aggregate level. However, only four subsectors are characterized by an inverted U-shaped relationship and none of them are significant.

To conclude, we provide empirical evidence of a U-shaped relationship between development and the labor share within sectors which is neither related to factor accumulation nor to openness.

\section{A simple model}

In this section, we consider the workhorse model of economic development focusing on occupational choices. We present an adapated version of Banerjee and Newman [4] in the simplified form of Ghatak and Jiang [17]. We only focus on the static part of the model since we are not interested in the engine of development which is outside the scope of the present paper and which would induce complex dynamics (see Banerjee and Newman [4]). Here we only consider the consequences of development on the labor share and show that it induces a U-shaped pattern, consistent with our empirical findings. Importantly, the model implies changes in the labor share that occur within sectors as entrepreneurs shift from traditional technologies to modern ones within a sector. This is consistent with our empirical finding which suggests that the U-shaped pattern is not related to composition effects.

\subsection{Model environment}

There are two production technologies. The traditional one does not need capital and uses two units of labor to produce $y_{T}$. The modern technology uses $I$ units of capital and two units of labor to produce $y_{M}$. One unit is provided by the entrepreneur and the other by a worker. Modern technology generates a surplus in the sense that $y_{M}-r I>y_{T}$, where $r$ is the exogenous interest rate. Population is normalized to one, $a_{i}$ corresponds to the wealth of an individual $i$ and $w$ is the competitive wage rate.

An agent can : 
- work with an associated payoff of $w+r a_{i}$

- become an entrepreneur in the traditional sector and get a payoff of $y_{T}-w+r a_{i}$

- become an entrepreneur in the modern sector and get a payoff of $y_{M}-w+r\left(a_{i}-I\right)$.

In the traditional sector, firms generally correspond to family firms or even to self-employed individuals and they are generally much smaller than firms in the modern sector. However, it does not affect our results to consider the possibility for modern technology to operate with multiple workers and for traditional ones to be self-employed individuals. We assume that the credit market is not perfect and we call $G(a)$ the cumulative distribution of the wealth $a_{i}$. As in Banerjee and Newman [4], the credit market is subject to transaction costs due to the imperfect enforcement of loan contracts. A borrower may default on his loan, get caught with some probability $\pi$ and pay a fixed $\operatorname{cost} F$. As a result in order to get a loan, the level of wealth has to be sufficiently high in order to ensure a higher payoff in case of debt repayment than in case of default:

$$
y_{M}-w-r\left(I-a_{i}\right) \geq y_{M}-w-\pi F
$$

which implies

$$
a_{i} \geq I-\pi F / r
$$

As a result only a proportion $1-G(I-\pi F / r)$ of individuals can enter the modern sector. The labor market is competitive and we can define two wages. First, $\underline{w}$ is the wage rate at which an individual in the traditional sector is indifferent between working as a wage-earning worker and become an entrepreneur. Therefore $\underline{w}$ is such that $\underline{w}=y_{T}-\underline{w}$ which implies $\underline{w}=$ $y_{T} / 2$. Second, $\bar{w}$ is the wage rate at which an individual in the modern sector is indifferent between working as a wage-earning worker and become an entrepreneur. Therefore $\bar{w}$ is such that $\bar{w}+r a_{i}=y_{M}-\bar{w}+r\left(a_{i}-I\right)$, which implies $\bar{w}=\left(y_{M}-r I\right) / 2$. Note that $\bar{w}>\underline{w}$ since we assumed $y_{M}-r I>y_{T}$.

The labor market equilibrium wage rate is straightforward to derive. Consider first the labor supply. When $w<\underline{w}$, labor supply is 0 since all agents prefer to become entrepreneur in the modern sector for those which have a sufficient wealth (the proportion $[1-G(I-\pi F / r)]$ of the population) or in the traditional sector for credit constrained agents. Labor demand exceeds labor supply as a result. When $w=\underline{w}$, labor supply can be any point in $[0, G(I-\pi F / r)]$ since a 
proportion $[G(I-\pi F / r)]$ of the population is indifferent between working as a laborer or become an entrepreneur in the traditional sector ; the remaining proportion $[1-G(I-\pi F / r)]$ strictly prefers becoming an entrepreneur in the modern sector since $\bar{w}>\underline{w}$. Using the same arguments, if $w \in] \underline{w} ; \bar{w}[$, labor supply is $[G(I-\pi F / r)]$. When $w=\bar{w}$ labor supply can be any point in $[G(I-\pi F / r) ; 1]$. When $w>\bar{w}$ labor supply is 1 and clearly exceeds labor demand.

We then derive labor demand. When $w>\bar{w}$, labor demand is 0 . When $w=\bar{w}$, labor demand can be any point in $[0 ; 1-G(I-\pi F / r)]$ and when $w \in] \underline{w} ; \bar{w}[$ labor demand is at the maximum, that is $[1-G(I-\pi F / r)]$. When $w<\underline{w}$ labor demand is 1 since everyone becomes an entrepreneur (whether it be in the modern sector or in the traditional one for those who are credit constrained). We can easily compute the equilibrium wage:

$$
\begin{aligned}
& w^{*}=\bar{w} \text { if } 1-G(I-\pi F / r)>1 / 2 \\
& w^{*}=\underline{w} \text { if } 1-G(I-\pi F / r)<1 / 2 \\
& w^{*} \in[\underline{w} ; \bar{w}] \text { if } G(I-\pi F / r)=1 / 2
\end{aligned}
$$

We can now compute the labor share of income for the two different wage regimes.

When $1-G(I-\pi F / r)<1 / 2$, then, $w^{*}=\underline{w}$. A proportion $1-G(I-\pi F / r)$ of individuals enters the modern sector to produce $y_{M}$, whereas a proportion $G(I-\pi F / r)-1 / 2$ becomes entrepreneurs in the traditional one to produce $y_{T}$. Finally a proportion $1 / 2$ becomes laborers.

Since the labor share can be defined as the wage bill over value added, the labor share in the first regime is:

$$
L S(w=\underline{w})=\frac{\underline{w} / 2}{(1-G(I-\pi F / r)) y_{M}+(G(I-\pi F / r)-1 / 2) y_{T}} .
$$

Under the alternative wage regime, that is when when $[1-G(I-\pi F / r)>1 / 2]$, the equilibrium wage rate is $w^{*}=\bar{w}$. A proportion $1 / 2$ of population becomes entrepreneur in the modern sector and produces $y_{M}$ while the remaining proportion becomes laborer. The labor share in this regime is:

$$
L S(w=\underline{w})=\frac{\bar{w}}{y_{M}} .
$$




\subsection{Labor share and development}

We can now study the impact of the development process on the labor share of income. Banerjee and Newman [4] or Ghatak and Jiang [17] modelize the development through inherited wealth. In their model, an active generation gives a fixed share of their income to their offspring and this modifies the proportion of agents which are credit constraint $(G(I-\pi F / r))$ the next period. We do not modelize the dynamic process since we simply focus on the consequences of development in term of the labor share of income. Ghatak and Jiang [17] precisely derive the condition in terms of initial wealth distribution under which economy can converge to the high wage regime $\bar{w}$ or remain stuck in a development trap with low wages $\underline{w}$ due to insufficient number of agents able to enter the modern sector. In their model, development (which we consider exogenous here) is characterized by a decrease in the proportion of credit constrained agents due to the dynamics of wealth accumulation in the economy. In other word, the proportion of modern firms in the economy increases with economic development. ${ }^{9}$

Under the low wage regime, the impact on the labor share is clearly negative:

$$
\frac{\partial L S}{\partial(1-G(I-\pi F / r))}<0 \text { if } w=\underline{w} .
$$

The result is intuitive. As the proportion of modern firms in the economy increases, the GDP increases but wages remains low and related to the traditional firm productivity due to insufficient labor demand. As a result the labor share mechanically decreases with GDP. This result is related to the seminal work of Lewis [26]. He argues that labor supply in the modern sector of the economy

\footnotetext{
${ }^{9}$ For instance we can easily compute one of the possible development path of this model. Each agent give a share $s$ of total income to its offspring (due to Cobb Douglas preferences). Wealth dynamics is straightforward to compute. For a worker, this is simply:

for a traditional entrepreneur$$
a_{t+1}=w+r a_{t}
$$

and for a modern entrepreneur

$$
a_{t+1}=\underline{w}+r a_{t}
$$

$$
\begin{aligned}
& a_{t+1}=\bar{w}+r a_{t} \text { if } w=\bar{w} \\
& a_{t+1}=y_{M}-\underline{w}+r\left(a_{t}-I\right) \text { if } w=\underline{w}
\end{aligned}
$$

We can derive the steady state wealth for each cathegory of agents: $a^{W}=w /(1-r)$ for workers, $a^{T}=w /(1-r)$ for traditional entrepreneurs and $a^{M}(w=\bar{w})=\bar{w} /(1-r)$ or $a^{M}(w=\underline{w})=\left(y_{M}-\underline{w}-r I\right) /(1-r)$ for modern entrepreneurs depending on the wage regime. Let's start with an initial wealth distribution such that $G_{0}(I-\pi F / r)>$ $1 / 2$ which gives an equilibrium wage $w=\underline{w}$. Note that by definition $a^{W}(w=\underline{w})<a^{W}(w=\bar{w})=a^{M}(w=\bar{w})<$ $a^{M}(w=\underline{w})$. If parameters are such that $\left(y_{M}-\underline{w}-r I\right) /(1-r)>\bar{w} /(1-r)=a^{W}(w=\bar{w})=a^{M}(w=\bar{w})>a^{W}(w=$ $\underline{w})>I-\pi F / r$. In such a case, the capital accumulation process induce tradition entrepreneurs or workers agents offspring to switch to a modern entrepreneur occupation at one point when dynasty has accumilated enough capital. At one date $t^{*}$, as less individual become credit constraint, the distribution is such that $G_{t^{*}}(I-\pi F / r)>1 / 2$ and the economy switch to the high wage regime $w=\bar{w}$.
} 
is unlimited which gives market power to modern firms in setting wages. In such a dual economy framework, a modern firm enjoys rents due to insufficient labor demand from modern firms and from the resulting low equilibrium wage. In this environment, labor share decreases along the development path when economy is under the low wage regime $w=\bar{w}$. When labor demand from modern firms becomes sufficiently high $(G(I-\pi F / r)<1 / 2)$, wages jump from low to high level and rents in the modern sector disappear. This results in a clear increase in the labor share.

The development process is also characterized by an increase in firms productivity. This increase may be asymmetric in the sense that modern firms may benefit more than traditional ones from an increase in the quality of the workforce or from technological change. The impact of an increase in $y_{M}$ on the labor share is negative when wages are low $(w=\underline{w})$ since $\underline{w}$ only depends on the productivity of traditional firms $y_{T}$. When wages are high $(w=\bar{w})$ and $I$ is fixed, the impact of an increase in $y_{M}$ on the labor share is negative. This result is due to the fact $\bar{w}$ is not strictly proportional to productivity $y_{M}$ since $\bar{w}=\left(y_{M}-r I\right) / 2$. One way of avoiding this result and obtaining a constant labor share when productivity increases, is to assume that the entry cost $I$ is proportional to productivity. If $I=k y_{M}$, where $k$ is a proportionality coefficient, it is obvious to see that $\partial L S / \partial y_{M}=0$ when $w=\bar{w}$ (developed countries).

In this model, the duality of the economy in terms of firms productivity comes from credit market imperfections. However other mechanisms have been highlighted in the literature. For instance, La Porta and Shleifer [32] show that traditional firms are run by poorly educated managers contrary to high productivity firms. They suggest that a lack of well-educated managers limits the entry in the modern sector in which technology is complementary to skills. Acemoglu [1] argues that rulers may limit the entry in the modern sector in order to generate rents for the elite connected to entrepreneurs. Finally, Parente and Prescott [34] argue that the lack of competition in developing countries is an important factor in explaining the lower GDP per capita compared to developed ones.

In the basic model that we presented, the labor share jumps to its long run equilibrium level when labor demand from modern firms becomes sufficiently high. This generates a U-shaped pattern between development and the labor share. We present in an online appendix an alternative version of the model that features frictions on the labor market which induces a less extreme wage determination process and which avoids a jump in the labor share. The latter model is more general and does rely explicitly on credit market imperfections. Results remains qualitatively unchanged. 


\section{Conclusion}

We highlighted a strong correlation between development and the labor share of income at the aggregate manufacturing level but also within manufacturing subsectors which suggests that this correlation is not due to reallocation forces across subsectors. We also controlled for factor accumulation in order to understand if changes in the labor share during the development process is related to changes in factor intensities. We showed that this does not affect the U-shaped relationship that we found between development and the labor share.

We then argued that standard models in development economics that feature duality can account for such a pattern. Using a simplified version of the Banerjee and Newman [4] or Ghatak and Jiang [17] frameworks, we show that such models generate a U-shaped pattern for the labor share under plausible assumptions. The intuition is : at early stages of development, many agents are credit constrained and only few of them can enter the modern sector to manage high productivity firms. At this stage, the labor demand from high productivity firms is low and so wages reflect the low productivity of traditional firms. Therefore the number of high productivity firms increases but wages remain stuck at low levels due to insufficient labor demand. The aggregate labor share decreases as a result. At one point, enough entrepreneurs enter the modern sector and the labor demand becomes too high. The traditional sector disappears, wages increase and the labor share increases as a result.

This pattern is relevant when thinking of the Chinese economy. Recently, strong tensions have started to emerge on the labor market due to an insufficient number of job seekers compared to vacant jobs. As a result, wages started to increase quickly, deteriorating the competitivity of many firms in the economy and leading to the slowdown that the Chinese economy currently experiments.

The link between development and inequality à la Kuznets has always been controversial and not very robust empirically. This lack of consensus can be seen as going against the validity of our U-shaped relationship but actually, the link between factor and personal income distribution is not a one to one relationship. We actually stress that the Kuznets curve is valid when examining the link between development and the labor share, a particular measure of income inequality.

We leave several research issues of our paper to future work. First, it would be interesting to explore the impact of development using micro level data on firms to study the sharing of the value added directly at the firm level. Second, other issues not studied in the theoretical model are related to the location choice of entrepreneurs, to the expansion of entrepreneurship during 
the development process and to whether the growth of the modern sector comes from new or existing entrepreneurs. In our model, all of those aspects of development are taken as exogenous. We chose to keep the model as simple and tractable as possible in order to focus our attention on the consequences of the duality of labor market on the sharing of the value added. Finally, we do not modelize many implications that such a pattern of the labor share may have, for instance the competitivity of firms in the exports market, global imbalances or within countries migration led by economic development. These questions remain open and we leave them for future research.

\section{A Appendix}

\section{A.1 Data}

\section{UNIDO data}

We compute the labor shares and the investment-output ratios from the industrial statistics of UNIDO (United Nations Industrial Development Organization). All data are are originally stored in national currency at current prices. Since these variables are ratio we do not have to convert them from national currency into a common currency.

Wages and salaries: All payment in cash or in kind paid to "employees", including direct wages and salaries, remuneration for time not worked, bonuses and gratuities, housing and family allowances paid directly by the employer and payment in kind. Despite UNIDO recommendation, there can remain employer's social security contributions, pensions and insurance schemes, as well as the benefits received by employees under these schemes, and severance and termination pay.

Value added: Value of the output less value of the inputs, which covers the value of materials and supplies for production and cost of industrial services received. Can be at factor cost (i.e. excluding indirect taxes minus the subsidies) or at market cost (including indirect taxes minus the subsidies), depending on the treatment.

Gross fixed capital formation: Refers to the value of purchases and own-account construction of fixed assets during the reference year less the value of corresponding sales. The fixed assets covered are those (whether new or used) with a productive life of one year or more.

\section{A.2 List of developing countries in UNIDO data}

The developing countries where the labor share and the control variables are observable are: 
Bangladesh, Barbados, Bolivia, Botswana, Cameroon, Central African Republic, Chile, Colombia, Congo, Costa Rica, Ecuador, Egypt, El Salvador, Ethiopia, Fiji, Gambia, Guatemala, Honduras, Hungary, India, Indonesia, Iran, Iraq, Jamaica, Jordan, Kenya, Malawi, Malaysia, Nepal, Nicaragua, Niger, Pakistan, Panama, Peru, Philippines, Poland, Senegal, South Africa, Sri Lanka, Swaziland, Thailand, Togo, Trinidad and Tobago, Tunisia, Turkey, Uruguay, Venezuela, Zambia, Zimbabwe. 


\section{A.3 Descriptive statistics}

The following table provides descriptive statistics of the key variables in the UNIDO data at the aggregate manufacturing level.

\begin{tabular}{|c|cccc|}
\hline & Mean & Standard deviation & Min. & Max. \\
\hline Labor share & 31.64 & 13.68 & 5.21 & 80.37 \\
$I / Y$ & 0.25 & 0.31 & -0.17 & 3.32 \\
OPENT & 61.59 & 37.53 & 8.10 & 217.57 \\
OPENK & -0.53 & 1.17 & -1.75 & 2.62 \\
School & 4.14 & 1.99 & 0.47 & 9.63 \\
\hline
\end{tabular}

\section{A.4 List of the manufacturing subsectors}

\begin{tabular}{|c|c|}
\hline Isicccode & Subsector \\
\hline 311 & Food products \\
313 & Beverage \\
314 & Tobacco \\
321 & Textile \\
322 & Wearing apparel, except footwear \\
323 & Leather products \\
324 & Footwear, except rubber or plastic \\
331 & Wood Products \\
332 & Furniture, except metal \\
341 & Paper and products \\
342 & Printing and publishing \\
351 & Industrial chemicals \\
352 & Other chemicals \\
353 & Petroleum refineries \\
354 & Misc. petroleum and coal products \\
355 & Rubber products \\
356 & Plastic products \\
361 & Pottery, china, earthenware \\
362 & Glass and products \\
369 & Other non-metallic mineral products \\
371 & Iron and steel \\
372 & Non ferrous metal \\
381 & Fabricated metal products \\
382 & Machinery, except electrical \\
383 & Machinery, electric \\
384 & Transport equipment \\
385 & Professional and scientific equipment \\
390 & Other manufactured products \\
\hline
\end{tabular}




\section{A.5 Sectoral regressions with time, country and sector fixed effects}

Table A1 presents the results of the model presented in equation (4):

$$
\begin{aligned}
L S_{i t s}= & a+a_{i}+a_{t}+a_{s} \\
& +\beta_{1} G D P_{i, t-1}+\beta_{2} G D P_{i, t-1}^{2}+\beta_{3} I / Y_{i, t-1, s} \\
& +\beta_{4} O P E N T_{i, t-1}+\beta_{5} O P E N K_{i, t-1}+\beta_{6} \text { School }_{i, t-1}+\varepsilon_{i t s},
\end{aligned}
$$

where the impact of development on the labor share is controlled by time, country and sector fixed effects.

Table A1: Development and the labor share: sectoral data on developing countries

\begin{tabular}{llllll}
\hline \hline & $(1)$ & $(2)$ & $(3)$ & $(4)$ & $(5)$ \\
\hline$G D P$ & $-45.055^{*}$ & $-69.192^{*}$ & $-64.656^{*}$ & $-107.886^{* * *}$ & $-111.714^{* * *}$ \\
$G D P^{2}$ & $(23.364)$ & $(36.011)$ & $(35.807)$ & $(33.108)$ & $(34.764)$ \\
& $2.728^{*}$ & $4.411^{* *}$ & $4.173^{* *}$ & $6.928^{* * *}$ & $7.180^{* * *}$ \\
$I / Y$ & $(1.394)$ & $(2.082)$ & $(2.067)$ & $(1.925)$ & $(2.048)$ \\
& & -0.000 & -0.000 & 0.000 & 0.000 \\
OPENT & & $(0.004)$ & $(0.004)$ & $(0.004)$ & $(0.004)$ \\
OPENK & & -0.022 & -0.029 & -0.042 & \\
& & & $(0.049)$ & $(0.065)$ & $(0.075)$ \\
School & & & & $2.263^{* * *}$ & $2.432^{* * *}$ \\
& & & & $(0.601)$ & $(0.693)$ \\
Constant & & & & & 0.278 \\
& & & & & $(1.525)$ \\
R-squared & $195.213^{* *}$ & $349.308^{* *}$ & $287.310^{*}$ & $409.416^{* * *}$ & $414.759^{* * *}$ \\
Nb of Observations & $(99.248)$ & $(155.219)$ & $(157.086)$ & $(145.258)$ & $(158.814)$ \\
\hline
\end{tabular}

Clustered standard errors in brackets. $p<0.10,{ }^{* *} p<0.05,{ }^{* * *} p<0.01$ 


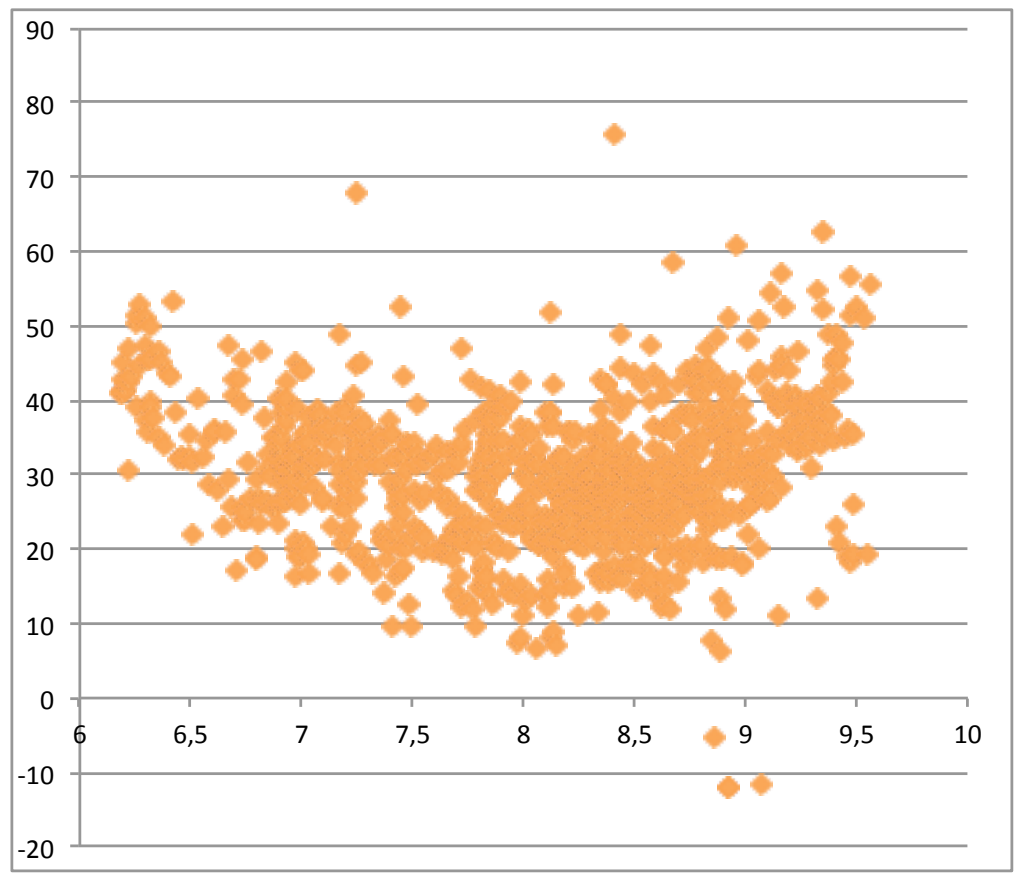

Figure 2: Development and the labor share: the Kuznets hypothesis 


\section{A.6 Regressions within each subsectors}

Table A2: Development and the labor share : regressions within each sector

\begin{tabular}{|c|c|c|c|c|c|c|}
\hline Sectors & S311 & S313 & S314 & S321 & S322 & S323 \\
\hline$G D P$ & $\begin{array}{l}-125.414^{* * *} \\
(44.452)\end{array}$ & $\begin{array}{l}-111.689^{* *} \\
(44.881)\end{array}$ & $\begin{array}{l}-391.767 \\
(256.283)\end{array}$ & $\begin{array}{l}6.209 \\
(349.230)\end{array}$ & $\begin{array}{l}-297.642 \\
(286.128)\end{array}$ & $\begin{array}{l}506.478 \\
(762.982)\end{array}$ \\
\hline$G D P^{2}$ & $\begin{array}{l}8.104^{* * *} \\
(2.629)\end{array}$ & $\begin{array}{l}6.452^{* *} \\
(2.747)\end{array}$ & $\begin{array}{l}25.165 \\
(16.435)\end{array}$ & $\begin{array}{l}4.532 \\
(20.704)\end{array}$ & $\begin{array}{l}12.180 \\
(16.316)\end{array}$ & $\begin{array}{l}-28.231 \\
(45.116)\end{array}$ \\
\hline$I / Y$ & $\begin{array}{l}-0.826 \\
(1.396)\end{array}$ & $\begin{array}{l}4.354^{* *} \\
(1.998)\end{array}$ & $\begin{array}{l}-0.508 \\
(8.186)\end{array}$ & $\begin{array}{l}-42.850 \\
(44.253)\end{array}$ & $\begin{array}{l}-51.576^{* *} \\
(19.942)\end{array}$ & $\begin{array}{l}-1.598 \\
(3.201)\end{array}$ \\
\hline$O P E N T$ & $\begin{array}{l}-0.047 \\
(0.096)\end{array}$ & $\begin{array}{l}-0.010 \\
(0.053)\end{array}$ & $\begin{array}{c}-0.758 \\
(0.597)\end{array}$ & $\begin{array}{l}0.064 \\
(0.381)\end{array}$ & $\begin{array}{l}1.295 \\
(1.359)\end{array}$ & $\begin{array}{l}-0.901 \\
(0.581)\end{array}$ \\
\hline$O P E N K$ & $\begin{array}{l}2.697^{* *} \\
(1.218)\end{array}$ & $\begin{array}{l}0.128 \\
(0.729)\end{array}$ & $\begin{array}{l}-1.156 \\
(1.893)\end{array}$ & $\begin{array}{l}14.302 \\
(14.468)\end{array}$ & $\begin{array}{l}7.992 \\
(8.730)\end{array}$ & $\begin{array}{l}-3.087 \\
(8.896)\end{array}$ \\
\hline School & $\begin{array}{l}-0.129 \\
(2.909)\end{array}$ & $\begin{array}{l}0.680 \\
(2.355)\end{array}$ & $\begin{array}{l}5.003 \\
(5.926)\end{array}$ & $\begin{array}{l}-5.389 \\
(11.599)\end{array}$ & $\begin{array}{l}-14.584 \\
(20.467)\end{array}$ & $\begin{array}{l}23.097 \\
(23.377)\end{array}$ \\
\hline Constant & $\begin{array}{l}491.300^{* * *} \\
(179.493)\end{array}$ & $\begin{array}{l}478.677^{* *} \\
(183.480)\end{array}$ & $\begin{array}{l}1497.481 \\
(973.971)\end{array}$ & $\begin{array}{l}-167.735 \\
(1422.504)\end{array}$ & $\begin{array}{l}1948.362 \\
(1685.436)\end{array}$ & $\begin{array}{l}-2380.346 \\
(3313.723)\end{array}$ \\
\hline R-squared & 0.624 & 0.703 & 0.198 & 0.384 & 0.181 & 0.149 \\
\hline $\mathrm{Nb}$ of Observations & 456 & 437 & 404 & 441 & 400 & 398 \\
\hline
\end{tabular}

Clustered standard errors in brackets.

$p<0.10,{ }^{* *} p<0.05$, *** $p<0.01$

All regressions include time fixed effects and country fixed effects. 
Table A3: Development and the labor share : regressions within each sector

\begin{tabular}{|c|c|c|c|c|c|c|}
\hline Sectors & "S324 & S331 & S332 & S341 & S342 & S351 \\
\hline$G D P$ & -197.001 & -93.706 & $-293.706^{* * *}$ & $-140.449 * *$ & -282.578 & -178.677 \\
\hline$G D P^{2}$ & $\begin{array}{l}12.676 \\
(9.950)\end{array}$ & $\begin{array}{l}6.933 \\
(4.387)\end{array}$ & $\begin{array}{l}18.395^{* * *} \\
(3.585)\end{array}$ & $\begin{array}{l}8.332^{* *} \\
(3.859)\end{array}$ & $\begin{array}{l}18.848^{*} \\
(11.049)\end{array}$ & $\begin{array}{l}11.283^{*} \\
(6.639)\end{array}$ \\
\hline$I / Y$ & $\begin{array}{l}-0.501 \\
(0.328)\end{array}$ & $\begin{array}{l}-0.811 \\
(2.018)\end{array}$ & $\begin{array}{l}-2.869 \\
(3.021)\end{array}$ & $\begin{array}{l}0.817 \\
(0.900)\end{array}$ & $\begin{array}{l}-42.737 \\
(38.949)\end{array}$ & $\begin{array}{l}0.243 \\
(0.430)\end{array}$ \\
\hline$O P E N T$ & $\begin{array}{l}-0.123 \\
(0.082)\end{array}$ & $\begin{array}{l}-0.097 \\
(0.085)\end{array}$ & $\begin{array}{l}-0.256^{* * *} \\
(0.072)\end{array}$ & $\begin{array}{l}-0.140 \\
(0.098)\end{array}$ & $\begin{array}{l}-0.035 \\
(0.179)\end{array}$ & $\begin{array}{l}-0.229 \\
(0.177)\end{array}$ \\
\hline$O P E N K$ & $\begin{array}{l}0.480 \\
(1.947)\end{array}$ & $\begin{array}{l}-0.401 \\
(1.558)\end{array}$ & $\begin{array}{l}-0.093 \\
(1.343)\end{array}$ & $\begin{array}{l}4.635 \\
(3.360)\end{array}$ & $\begin{array}{l}0.468 \\
(1.178)\end{array}$ & $\begin{array}{l}6.316^{*} \\
(3.299)\end{array}$ \\
\hline School & $\begin{array}{l}4.838^{*} \\
(2.662)\end{array}$ & $\begin{array}{l}-0.671 \\
(4.035)\end{array}$ & $\begin{array}{l}-1.135 \\
(3.756)\end{array}$ & $\begin{array}{l}-3.918 \\
(3.430)\end{array}$ & $\begin{array}{l}-12.494 \\
(10.884)\end{array}$ & $\begin{array}{l}-4.273 \\
(5.083)\end{array}$ \\
\hline Constant & $\begin{array}{l}775.433 \\
(720.038)\end{array}$ & $\begin{array}{l}326.892 \\
(265.383)\end{array}$ & $\begin{array}{l}1157.006^{* * *} \\
(243.113)\end{array}$ & $\begin{array}{l}586.671^{* *} \\
(276.675)\end{array}$ & $\begin{array}{l}1189.688 \\
(800.150)\end{array}$ & $\begin{array}{l}792.449 \\
(485.587)\end{array}$ \\
\hline R-squared & 0.495 & 0.551 & 0.664 & 0.390 & 0.435 & 0.260 \\
\hline $\mathrm{Nb}$ of Observations & 395 & 446 & 397 & 439 & 417 & 42 \\
\hline
\end{tabular}

Clustered standard errors in brackets.

$p<0.10,{ }^{* *} p<0.05,{ }^{* * *} p<0.01$

All regressions include time fixed effects and country fixed effects. 
Table A4: Development and the labor share : regressions within each sector

\begin{tabular}{|c|c|c|c|c|c|c|}
\hline Sectors & S352 & S353 & S354 & S355 & S356 & S361 \\
\hline$G D P$ & $\begin{array}{l}-67.706 \\
(64.771)\end{array}$ & $\begin{array}{l}139.342 \\
(194.135)\end{array}$ & $\begin{array}{c}-30.730 \\
(75.173)\end{array}$ & $\begin{array}{l}-57.374 \\
(68.043)\end{array}$ & $\begin{array}{l}-147.899^{* * *} \\
(42.290)\end{array}$ & $\begin{array}{l}-125.045 \\
(114.675)\end{array}$ \\
\hline$G D P^{2}$ & $\begin{array}{l}4.499 \\
(3.856)\end{array}$ & $\begin{array}{l}-9.332 \\
(12.206)\end{array}$ & $\begin{array}{l}1.876 \\
(4.802)\end{array}$ & $\begin{array}{l}4.239 \\
(4.213)\end{array}$ & $\begin{array}{l}9.090^{* * *} \\
(2.496)\end{array}$ & $\begin{array}{l}7.708 \\
(6.969)\end{array}$ \\
\hline$I Y$ & $\begin{array}{l}3.088 \\
(3.470)\end{array}$ & $\begin{array}{l}6.448^{* *} \\
(3.026)\end{array}$ & $\begin{array}{l}2.593^{*} \\
(1.267)\end{array}$ & $\begin{array}{l}4.068^{* * *} \\
(1.356)\end{array}$ & $\begin{array}{l}1.257 \\
(1.793)\end{array}$ & $\begin{array}{c}-0.003^{*} \\
(0.001)\end{array}$ \\
\hline OPENT & $\begin{array}{l}-0.076 \\
(0.061)\end{array}$ & $\begin{array}{l}0.236 \\
(0.260)\end{array}$ & $\begin{array}{l}-0.180 \\
(0.121)\end{array}$ & $\begin{array}{l}-0.138 \\
(0.099)\end{array}$ & $\begin{array}{l}-0.136^{* *} \\
(0.062)\end{array}$ & $\begin{array}{l}0.061 \\
(0.092)\end{array}$ \\
\hline$O P E N K$ & $\begin{array}{l}2.100 \\
(1.561)\end{array}$ & $\begin{array}{l}1.031 \\
(1.346)\end{array}$ & $\begin{array}{l}1.943 \\
(1.636)\end{array}$ & $\begin{array}{l}3.496^{* *} \\
(1.470)\end{array}$ & $\begin{array}{l}1.870 \\
(1.588)\end{array}$ & $\begin{array}{l}0.229 \\
(1.687)\end{array}$ \\
\hline School & $\begin{array}{l}1.470 \\
(2.812)\end{array}$ & $\begin{array}{l}3.498 \\
(5.760)\end{array}$ & $\begin{array}{l}4.650 \\
(2.783)\end{array}$ & $\begin{array}{l}1.868 \\
(3.444)\end{array}$ & $\begin{array}{l}1.454 \\
(3.084)\end{array}$ & $\begin{array}{l}0.838 \\
(2.136)\end{array}$ \\
\hline Constant & $\begin{array}{l}244.747 \\
(280.765)\end{array}$ & $\begin{array}{l}-557.488 \\
(787.680)\end{array}$ & $\begin{array}{l}148.407 \\
(289.402)\end{array}$ & $\begin{array}{l}228.575 \\
(264.378)\end{array}$ & $\begin{array}{l}626.830^{* * *} \\
(192.692)\end{array}$ & $\begin{array}{l}515.128 \\
(482.405)\end{array}$ \\
\hline R-squared & 0.522 & 0.490 & 0.520 & 0.599 & 0.319 & 0.531 \\
\hline $\mathrm{Nb}$ of Observations & 393 & 357 & 272 & 408 & 398 & 359 \\
\hline
\end{tabular}

Clustered standard errors in brackets.

$p<0.10,{ }^{* *} p<0.05$, *** $p<0.01$

All regressions include time fixed effects and country fixed effects. 
Table A5: Development and the labor share : regressions within each sector

\begin{tabular}{lllllll}
\hline \hline Sectors & S362 & S369 & S371 & S372 & S381 & S382 \\
\hline$G D P$ & -73.48 & -81.91 & -294.89 & -191.36 & $-150.35^{* *}$ & -6.31 \\
& $(84.63)$ & $(54.46)$ & $(206.68)$ & $(262.38)$ & $(60.93)$ & $(96.66)$ \\
$G D P^{2}$ & 3.83 & $5.48^{*}$ & 16.11 & 10.57 & $9.48^{* *}$ & 1.30 \\
& $(5.60)$ & $(3.22)$ & $(13.54)$ & $(16.80)$ & $(3.66)$ & $(5.57)$ \\
$I Y$ & 7.11 & $1.73^{*}$ & 0.29 & -0.60 & 2.14 & -1.54 \\
& $(6.72)$ & $(0.89)$ & $(2.93)$ & $(0.94)$ & $(2.64)$ & $(3.59)$ \\
OPENT & 0.11 & -0.06 & 0.90 & 0.65 & -0.12 & -0.12 \\
& $(0.25)$ & $(0.07)$ & $(1.14)$ & $(0.71)$ & $(0.09)$ & $(0.13)$ \\
OPENK & 5.37 & 1.42 & 2.56 & 1.08 & $2.21^{*}$ & 1.98 \\
& $(4.21)$ & $(0.95)$ & $(2.03)$ & $(2.20)$ & $(1.28)$ & $(2.14)$ \\
School & 4.83 & 2.05 & -17.37 & -18.75 & 0.04 & -5.42 \\
Constant & $(7.85)$ & $(2.65)$ & $(20.04)$ & $(12.06)$ & $(2.85)$ & $(5.97)$ \\
R-squared & 305.76 & 301.90 & 1223.77 & 1069.68 & $611.35^{* *}$ & 40.89 \\
Nb of Observations & $(346.68)$ & $(232.34)$ & $(786.40)$ & $(940.33)$ & $(239.72)$ & $(393.12)$ \\
\hline Clusterd & 0.23 & 0.69 & 0.28 & 0.28 & 0.66 & 0.50 \\
\hline
\end{tabular}

Clustered standard errors in brackets.

$p<0.10,{ }^{* *} p<0.05, * * * p<0.01$

All regressions include time fixed effects and country fixed effects. 
Table A6: Development and the labor share : regressions within each sector

\begin{tabular}{lllll}
\hline \hline Sectors & S383 & S384 & S385 & S390 \\
\hline$G D P$ & -69.25 & $-198.36^{*}$ & -97.50 & $-147.90^{* * *}$ \\
GDP & $(51.57)$ & $(117.21)$ & $(88.41)$ & $(42.29)$ \\
& 5.13 & $13.98^{*}$ & 5.73 & $9.09^{* * *}$ \\
$I Y$ & $(3.24)$ & $(7.37)$ & $(5.31)$ & $(2.50)$ \\
OPENT & $3.02^{*}$ & -7.45 & -2.07 & 1.26 \\
& $(1.52)$ & $(4.99)$ & $(1.45)$ & $(1.79)$ \\
OPENK & $-0.24^{* * *}$ & -0.23 & -0.02 & $-0.14^{* *}$ \\
& $(0.09)$ & $(0.14)$ & $(0.10)$ & $(0.06)$ \\
School & $2.95^{* * *}$ & 0.56 & 1.42 & 1.87 \\
& $(0.86)$ & $(1.74)$ & $(1.07)$ & $(1.59)$ \\
Constant & -1.03 & -1.80 & 3.67 & 1.45 \\
R-squared & $(2.80)$ & $(4.17)$ & $(2.62)$ & $(3.08)$ \\
Nb of Observations & 263.91 & 703.67 & 406.13 & $626.83^{* * *}$ \\
\hline
\end{tabular}

Clustered standard errors in brackets.

$p<0.10,{ }^{* *} p<0.05, * * * p<0.01$

All regressions include time fixed effects and country fixed effects. 


\section{A.7 Alternative model with frictions (Online appendix)}

In this appendix, we develop a more general model. As previously, the labor market is dual but we do not explicitly provide any microfundations. Labor market is characterized by frictions which make the wage determination process less extreme and prevents the labor share to jump suddendly.

\section{Environment}

We use a static matching model with entry costs in the goods market in the spirit of Daudey and Decreuse [12] or Decreuse and Maarek [13]. Our model differs in two aspects. First, we introduce a traditional sector specific to developing countries. Then we study the implication of the modern sector development through two different channels: an increase in modern sector productivity relative to the traditional sector productivity and a decrease in costs to enter the modern sector. There is a continuum of workers normalized to one and a continuum of firms of endogenous mass. Workers are homogenous whereas firms are not since modern and traditional firms differ in terms of productivity.

Each firm, modern or traditional, is endowed with a single job slot. Modern firms are more productive than traditional ones: the amount of output produced by a modern firm and a traditional firm is respectively $y_{M}$ and $y_{T}$ with $y_{M}>y_{T} .{ }^{10}$

Firm entry involves paying a cost that is proportional to the expected output. This cost can be interpreted in several ways. On the one hand, it can correspond to the purchase of capital units prior to searching for a worker. On the other hand, it can be due to the regulation that limits the number of firms and that guarantees superprofits for the firms which are able to enter. Blanchard and Giavazzi [8] consider such shadow costs to ensure that pure profits are not dissipated in entry costs. Capital costs and superprofits are part of the value added and do not coincide with labor income. Entry costs cannot correspond to expenses in intermediary goods (they would be subtracted from the value added) or to wage payments (they would enter the wage bill). More generally, this cost simply parametrizes the amount of rents on the good market wherever they come from. ${ }^{11}$

The cost per unit of output depends on whether the firm is modern or traditional. Modern

\footnotetext{
${ }^{10}$ The productivity differential may reflect several features of modern firms. First, modern firms benefit from better technology. Second, as noted by La Porta and Shleifer [32], modern firms benefit from better access to finance, have better educated managers and operate on markets which are different from those where traditional firms operate. As noted by La Porta and Shleifer [32], modern firms are bigger than traditional firms. Nevertheless, including the large firm dimension in a matching model would make the model more complicated and would not change the nature of our results.

${ }^{11}$ We will provide a larger interpretation on such a shadow cost later on in the paper when we focus on the impact of development.
} 
firms pay $c_{M}$, whereas traditional firms pay $c_{T}$. Modern firms face higher costs than traditional ones, that is $c_{M}>c_{T}$, and the entry cost differential $c_{M}-c_{T}$ reflects extra entry difficulties for firms to enter the modern sector. ${ }^{12}$

The labor market features matching frictions and is not segmented. Workers and vacancies meet according to the function $M=M(u, n)$, where $u$ stands for the effective number of jobseekers and $n$ stands for the number of vacancies. The meeting technology $M$ is homogenous of degree one to ensure that the unemployment rate does not depend on the number of traders in the economy. It is also increasing in both arguments, strictly concave, and bounded by $\min \{u, n\} .{ }^{13}$

Each worker is endowed with two search units - two applications- so $u=2$. The probability for a worker to receive an offer per search unit is $M(2, n) / 2=m(n)$; it is increasing in $n$. Similarly, $2 m(n) / n$ is the probability of a firm to find a worker, it is decreasing in $n$.

Firms set wages. If a worker receives a unique offer, which happens with a probability $2 m(n)(1-$ $m(n))$, then she/he is paid the monopsony wage. This monopsony wage is equal to the value of non market opportunities. Since without loss of generality the value of non market opportunities is normalized to zero, the monopsony wage is equal to zero and the firms gets the whole output. ${ }^{14}$ If a worker receives two offers, one from each application, then firms enter Bertrand competition to attach labor services. The probability of receiving two offers is $m(n)^{2}$. The wage then depends on the productivity of both firms. Let $\rho$ denote the proportion of modern firms in the economy. With probability $(1-\rho)^{2}$, the two offers are from traditional firms and the worker receives the output $y_{T}$. With probability $\rho(1-\rho)$, one of the offers comes from a modern firm and the other comes from a traditional firm. The worker is then hired by the modern firm and his wage is $y_{T}$ while the firm gets the difference $y_{M}-y_{T}$. With probability $\rho^{2}$, the two offers come from modern firms. The worker then obtains the marginal product $y_{M}$. Indeed, a firm unable to attract any workers cannot produce but has already paid the entry cost. ${ }^{15}$

In developing countries, an important share of traditional firms is not formally registered but

\footnotetext{
${ }^{12}$ The modern production sector often requires to comply with various regulations on the goods and labor market: for instance adapting the product to norms and legislations, a more complex production process with more partners which takes time to deal with before starting production. This explains the extra cost that firms have to incur to enter the modern sector.

${ }^{13}$ According to La Porta and Shleifer (2008), workers in the modern (formal) and the traditional (informal) sectors are not different in terms of observed skills or other observable characteristics. Only managers/entrepreneurs differ, being more educated in the modern sector than in the traditional one. This is the reason why we do not consider a specific labor market for the traditional sector.

${ }^{14}$ What matters here is that the monopsony wage is lower than the marginal productivity of labor. Thus there is a wedge between the maximum wage firms are willing to pay and the minimum wage that workers are ready to accept. In a dynamic setting, the monopsony wage would be equal to the endogenous reservation wage.

${ }^{15}$ Albrecht et al [3] provide a microfundation for such an equilibrium wage structure in a model in which firms post wages and workers have multiple applications (here, we have only two applications). Robin and Postel-Vinay [33] argue that an important part of wage dispersion cannot be explained by firms or employers characteristics.
} 
competes with formal traditional firms. Our goal is not to explain the size of the informal sector in the economy but it is important to take this feature into account in our model since informal firms do not appear either in the wage bill or in output statistics. We simply assume that a share $\delta$ of traditional firms are formal. ${ }^{16}$

In such a framework, the traditional sector (whether it be formal or informal) can be considered as residual in the sense that it is the sector in which workers search for a job when there is a lack of opportunities in the modern, formal sector. This is consistent with the view that the informal sector is mainly composed of traditional, archaic firms, as expressed by La Porta and Shleifer [32].

\section{Labor market equilibrium}

Expected profits for the two types of firms are:

$$
\begin{aligned}
\pi_{M} & =-c_{M} y_{M}+\frac{2 m(n)}{n}\left[(1-m(n)) y_{M}+m(n)(1-\rho)\left(y_{M}-y_{T}\right)\right] \\
\pi_{T} & =-c_{T} y_{T}+\frac{2 m(n)}{n}[1-m(n)] y_{T} .
\end{aligned}
$$

Firms enter the economy until profits cover costs. At the equilibrium we have $\pi_{I}=\pi_{F}=0$ so:

$$
\begin{aligned}
c_{M} & =\frac{2 m(n)}{n}\left[1-m(n)+m(n)(1-\rho) \frac{y_{M}-y_{T}}{y_{M}}\right], \\
c_{T} & =\frac{2 m(n)}{n}[1-m(n)] .
\end{aligned}
$$

These two equations simultaneously define $\rho$, the proportion of modern firms, and $n$, the total number of firms in this economy. The system can be solved recursively. The free-entry condition (8) for the traditional firms determines the total number of firms $n$. The free-entry condition (7) then determines the proportion of modern firms $\rho$. The fact that $c_{M}>c_{T}$ and $y_{M}>y_{T}$ implies that there exists a unique equilibrium with a non-zero proportion of modern firms.

The reason why the total number of firms depends only on the effective entry cost faced by traditional firms is the following. If $c_{M}$ decreases, then modern firms' profits become positive and new modern firms enter as a result. Since $c_{T}$ remains constant, profit expectations for traditional firms become negative because they find it more difficult to recruit a worker. The number of traditional firms goes down until the total number of firms returns to its initial value. Therefore,

\footnotetext{
${ }^{16}$ This is consistent with the evidence that La Porta and Shleifer [32] provide using the enterprise surveys of the World Bank which clearly show that in developing countries there is productive heterogeneity within the formal sector but that on average the productivity in the formal sector is substantially higher than in the informal one, which is mainly composed of traditional firms. We do not consider firm heterogeneity within sectors, whether it be modern, traditional or informal because it would not change our results.
} 
changes in modern firms' entry $\operatorname{cost} c_{M}$ do not modify the total number of firms and simply increase the proportion of modern firms. Indeed, applying the implicit function theorem to equations (7) and (8) shows that $d n / d c_{M}=0$ and $d \rho / d c_{M}<0$. An increase in productivity gap $\left(y_{M}-y_{T}\right) / y_{M}$ has effects similar to a fall in modern firms' entry $\operatorname{cost} c_{M}$, in that it increases the proportion of modern firms but it does not impact the total number of firms.

Entry costs correspond to the surplus that can be obtained on the goods market in such a framework. At this stage, shadow entry costs can receive an extra interpretation: they can correspond to all factors that affect the degree of competition and rents in the modern sector. They can be seen, as stated before, as regulatory barriers (shadow cost) which limit the number of firms in the modern sector and which guarantee superprofits to a reduced number of entrepreneurs. These regulatory barriers are very important in developing economies and are often introduced in order to give rents to politically connected entrepreneurs and to politicians. Djankov et al. [14] provide evidence of such barriers to entry in developing economies and argue they are consistent with public choice theories of regulation since they do not seem to correct any market failure. Parente and Prescott (1999) [34] argue that resulting lack of competition explain an important part of TFP differences with developed economies. Moreover, shadow entry costs can also correspond to the lack of resources that limits the size of the modern sector. For instance, low financial development and appropriates institution makes entrepreneurs credit constraint. This avoid entrepreneurs enter the modern sector and run high productivity firms (see Banerjee and Newman (1993) [4] for example). Finally, the technology used in the modern sector is highly intensive in human capital which is not very abundant in developing economies. La Porta and Shleifer [32] show that large formal modern firms are run by managers more educated than smaller informal firms whereas workers have pretty much the same observed characteristics in the modern and the traditional sector. They suggest that development goes together with the availability of high skilled entrepreneurs to run large and high productivity firms in the modern sector. Shadow entry costs can be interpreted as a lack of resources that makes the competition weak in the modern sector and guarantees superprofits as usually consider in dual model of economic development.

\section{The labor share}

The total wage bill paid by modern firms is:

$$
W_{M}=m(n)^{2} \rho\left[\rho y_{M}+2(1-\rho) y_{T}\right] .
$$


Indeed, the wage bill corresponds to workers who receive two offers. This event happens with probability $m(n)^{2}$. With probability $\rho^{2}$ the two offers are from modern firms and the worker receives the totality of output $y_{T}$. With probability $2 \rho(1-\rho)$, one of the two offers is from a traditional firm and the worker gets $y_{T}$.

The total wage bill paid by traditional firms is:

$$
W_{T}=m(n)^{2}(1-\rho)^{2} y_{T}
$$

Wages correspond to workers who receive two offers from traditional firms.

Total output in modern firms is:

$$
Y_{M}=m(n) \rho[2-m(n) \rho] y_{M}
$$

The probability that a worker does not receive a job offer from a modern firm is $(1-m(n) \rho)^{2}$; the probability that a worker receives an offer from such firms is $1-(1-m(n) \rho)^{2}$. However, the worker may receive two offers from such firms with probability $m(n)^{2} \rho^{2}$. In this case only one of the firms hires him/her. We therefore subtract $m(n)^{2} \rho^{2}$. The result follows.

Total output in traditional firms is:

$$
Y_{T}=m(n)(1-\rho)[2-m(n)(1+\rho)] y_{T} .
$$

The total wage bill in national account statistics is $W=W_{M}+\delta W_{T}$, whereas total output is $Y=Y_{M}+\delta Y_{T}$. This is due to the fact that many firms in the traditional sector are not registered and do not appear in official statistics. We obtain

$$
\mathrm{LS}=\frac{W}{Y}=\frac{m(n)\left[\rho^{2} y_{M}+2 \rho(1-\rho) y_{T}\right]+m(n) \delta(1-\rho)^{2} y_{T}}{\rho[2-m(n) \rho] y_{M}+\delta(1-\rho)[2-m(n)(1+\rho)] y_{T}}
$$

\section{The impact of development on the labor share}

In our mind, economic development goes together with the one of the modern sector as noted by La Porta and Shleifer [32]. Therefore we can argue that two essential features characterize economic development:

- A decrease in rents in the modern sector: (i) regulatory barriers to entry in the modern sector tend to decrease with development as suggested by Djankov et al [14] or Parente and 
Prescott [34]. (ii) the availability of resources such as educated managers able to run large and complex firms (and more broadly to take advantage of the modern sector technology or financial development) tends to increase the number of firms in the modern sector.

In our model, what parametrizes the amount of rents and the degree of competition in the modern sector is shadow entry costs $c_{M}$ whether they come from formal barriers to entry or from a lack of resource availability.

- An increase in the productivity gap between modern and traditional sector since the modern sector should benefit more from technological changes and productivity gains.

According to the free-entry conditions (7) and (8), changes in modern firms' entry costs only lead to changes in the proportion $\rho$ of modern firms in the total number of firms. To capture the impact of a decrease in modern sector entry costs, we only need to differentiate the labor share given by equation (13) with respect to $\rho$. We obtain:

$$
\frac{d \mathrm{LS}}{d \rho} \stackrel{\text { sign }}{\underline{\underline{n}}}-d Y / d \rho \times \mathrm{LS}+d W / d \rho
$$

Two opposite forces are involved: (i) the first term simply shows that at given wages an increase in the proportion of modern firms lowers the labor share since total output increases. This is the case if no modern firms compete to attract labor services. (ii) The second term corresponds to the increase in wages due to the entry of modern firms in the economy since this increases the probability that modern firms compete to attach labor services. At a given output, this increases the labor share.

The impact of modern firms' shadow entry costs on the labor share results from the interplay between these two forces. We have:

$$
\frac{d \mathrm{LS}}{d \rho} \stackrel{\operatorname{sign}}{=} \rho^{2} y_{M}-(1-\rho)^{2} y_{T}
$$

if $y_{M}-2 y_{T}+y_{T} \delta+m(n) y_{T}-m(n) y_{T} \delta>0$. This condition is likely to be satisfied. When $\delta=1$ it's clearly satisfied. Hence, $d \mathrm{LS} / d \rho$ is non-monotonic in $\rho$ : at first the labor share decreases, then reaches a minimum, and finally increases. Indeed, the labor share initially decreases with the development of the modern sector since the latter makes the output increase faster than wages because most of the workers' outside options are located in the traditional sector. With a larger proportion of modern firms, wages increase more rapidly than output since wage competition 
between modern firms becomes more frequent. The threshold proportion of modern firms $\rho^{*}$ below (respectively above) which modern sector development deteriorates (respectively improves) the labor share is given by $d \mathrm{LS} / d \rho=0$. We find that $\rho^{*}=\left[1+\left(y_{M} / y_{T}\right)^{1 / 2}\right]^{-1}$.

The pattern of the labor share as a function of the proportion of modern firms reflects the pattern of productive heterogeneity among firms. The labor share is the same when there are no modern firms ( $c_{M}$ sufficiently large, which implies that $\left.\rho=0\right)$ and when output is only produced by modern firms $\left(c_{T}=c_{M}\right.$, which implies that $\left.\rho=1\right)$. For these two extreme cases, LS $=m(n) /[2-$ $m(n)]$.

The second channel through which development could affect the labor share is a modification in the wedge between modern sector productivity and traditional sector productivity $\left(y_{M}-y_{T}\right) / y_{M}$. The impact on the labor share is more ambiguous. On the one hand, at a given proportion of modern firm $\rho$, an increase in the productivity gap clearly decreases the labor share of income since $\partial L S / \partial\left(y_{M}-y_{T}\right) / y_{M}<0$. Indeed, productivity increases for all modern firms but in many of them wages do not increase since outside options remain the same. On the other hand, the increase in productivity gap $\left(y_{M}-y_{T}\right) / y_{M}$ increases expected profits for firms in the modern sector and the proportion of modern firms $\rho$ increases. When $\rho$ is low, at first stages of development, both effects go in the same direction and the impact on the labor share is clearly negative. When $\rho$ is high, the impact is ambiguous since the two forces go in opposite directions. Recall that the threshold proportion of modern firms in the economy above which an increase in $\rho$ is decreasing in productivity differential is $\rho^{*}=\left[1+\left(y_{M} / y_{T}\right)^{1 / 2}\right]^{-1}$. Thus, the negative impact that the productivity gap $\left(y_{M}-y_{T}\right) / y_{M}$ between the modern and the traditional sector has on the labor share at first stages of development can contribute to explain the strong decrease in the labor share for low income economies during the development process.

Finally, for the sake of simplicity, we do not consider capital as an input in the model and we assume that firms' owners and workers simply bargain over total output. Including capital as an endogenous variable in the model would imply that workers and firms' owners would bargain over $(1-\alpha(k)) y, k$ being the quantity of capital per worker, and $\alpha$ the competitive capital share, which would depend on the level of capital accumulation. However, if production functions are Cobb-Douglas and identical in the two sectors, capital accumulation plays no role in changes in the labor share. Indeed in this latter case, the competitive capital share $\alpha$ would be the same in the two sectors and constant. We do not claim that technology is Cobb-Douglas but our empirical results suggest that factor accumulation plays no role in the relationship between development 
and the labor share. 


\section{Acknowledgments}

We thank Jo Thori Lind, Bruno Decreuse, Gilbert Cette, Pierre Cahuc, Rémi Baziller, Mickaël Melki, Gani Aldashev, Cecilia García Peñalosa, Andrew Newman as well as participants at the 2014 ASSET conference, at the 2011 LAGV, at the 2014 Applied Econometrics Workshop in Alicante, and at the seminars of the Universities of Orléans, Nancy and Rennes 1.

\section{References}

[1] Daron Acemoglu. A Simple Model of Inefficient Institutions. Scandinavian Journal of Economics, 108(4):515-546, December 2006.

[2] Daron Acemoglu and Veronica Guerrieri. Capital deepening and nonbalanced economic growth. Journal of Political Economy, 116(3):467-498, June 2008.

[3] James Albrecht, Pieter A. Gautier, and Susan Vroman. Equilibrium Directed Search with Multiple Applications. Review of Economic Studies, 73(4):869-891, 2006.

[4] Abhijit V Banerjee and Andrew F Newman. Occupational Choice and the Process of Development. Journal of Political Economy, 101(2):274-98, April 1993.

[5] Robert J Barro and Jong-Wha Lee. International data on educational attainment: Updates and implications. Oxford Economic Papers, 53(3):541-63, July 2001.

[6] R. Bazillier and B. Najman. Labour and financial crises: Is labour paying the price of the crisis? Mimeo, 2010.

[7] Samuel Bentolila and Gilles Saint-Paul. Explaining movements in the labor share. Contributions to Macroeconomics, 3(1):1103-1103, 2003.

[8] Olivier Blanchard and Francesco Giavazzi. Macroeconomic effects of regulation and deregulation in goods and labor markets. The Quarterly Journal of Economics, 118(3):879-907, August 2003.

[9] Francois Bourguignon and Christian Morrisson. Inequality and development: the role of dualism. Journal of Development Economics, 57(2):233-257, 1998.

[10] Daniele Checchi and Cecilia García-Peñalosa. Labour market institutions and the personal distribution of income in the oecd. Economica, 77(307):413-450, 072010. 
[11] Menzie D. Chinn and Hiro Ito. What matters for financial development? Capital controls, institutions, and interactions. Journal of Development Economics, 81(1):163-192, October 2006.

[12] Emilie Daudey and Bruno Decreuse. Higher education, employers' monopsony power and the labour share in the oecd countries. GREQAM working paper No 2006-13, 2006.

[13] Bruno Decreuse and Paul Maarek. Foreign direct investment and the labour share in developing countries: a theory and some evidence. Annals of Economics and Statistics (forthcoming), 2014 .

[14] Simeon Djankov, Rafael La Porta, Florencio Lopez-De-Silanes, and Andrei Shleifer. The Regulation of Entry. The Quarterly Journal of Economics, 117(1):1-37, February 2002.

[15] Gary S Fields. A Welfare Economic Approach to Growth and Distribution in the Dual Economy. The Quarterly Journal of Economics, 93(3):325-53, August 1979.

[16] Cecilia García-Peñalosa and Elsa Orgiazzi. Factor Components of Inequality: A CrossCountry Study. Review of Income and Wealth, 59(4):689-727, December 2013.

[17] Maitreesh Ghatak and Neville Nien-Huei Jiang. A simple model of inequality, occupational choice, and development. Journal of Development Economics, 69(1):205-226, October 2002.

[18] Douglas Gollin. Getting income shares right. Journal of Political Economy, 110(2):458-474, April 2002.

[19] A. Guscina. Effects of globalization on labor's share in national income. IMF Working Papers 06/294, International Monetary Fund, 2006.

[20] A.E. Harrison. Has globalization eroded labour's share? mimeo, University of California Berkeley, 2002.

[21] Arjun Jayadev. Capital account openness and the labour share of income. Cambridge Journal of Economics, 31:423-443, 2007.

[22] Kaldor. Alternatives theories of distribution. The Review of Economic Studies, 23(2):83-100, 1956.

[23] Loukas Karabarbounis and Brent Neiman. The Global Decline of the Labor Share. The Quarterly Journal of Economics, 129(1):61-103, 2014. 
[24] J B Knight. Explaining Income Distribution in Less Developed Countries: A Framework and an Agenda. Oxford Bulletin of Economics and Statistics, 38(3):161-77, August 1976.

[25] S. Kuznets. Economic growth and income inequality. The American Economic Review, $45(1): 1-28,1955$.

[26] W. Arthur Lewis. Economic development with unlimited supplies of labour. The Manchester School, 22:139-191, 1954.

[27] Jo Thori Lind and Halvor Mehlum. With or Without U? The Appropriate Test for a U-Shaped Relationship. Oxford Bulletin of Economics and Statistics, 72(1):109-118, 022010.

[28] Paul Maarek and Elsa Orgiazzi. Currency Crises and the Labour Share. Economica, 80(319):566-588, 072013.

[29] D. Ortega and F Rodriguez. Openness and factor shares. Mimeo, 2002.

[30] D. Ortega and F. Rodriguez. Are capital shares higher in poor countries? evidence from industrial surveys. Technical Report WP 2006-023, Wesleyan Economics, 2006.

[31] Thomas Piketty, editor. Le capital au 21e siècle . Editions du Seuil, September 2013.

[32] Rafael La Porta and Andrei Shleifer. The Unofficial Economy and Economic Development. Brookings Papers on Economic Activity, 39(2 (Fall)):275-363, 2008.

[33] Fabien Postel-Vinay and Jean-Marc Robin. Equilibrium Wage Dispersion with Worker and Employer Heterogeneity. Econometrica, 70(6):2295-2350, November 2002.

[34] Edward C. Prescott and Stephen L. Parente. Monopoly Rights: A Barrier to Riches. American Economic Review, 89(5):1216-1233, December 1999.

[35] Sherman Robinson. A Note on the U Hypothesis Relating Income Inequality and Economic Development. American Economic Review, 66(3):437-40, June 1976.

[36] Francisco Rodriguez and Arjun Jayadev. The Declining Labor Share of Income. Human Development Research Papers (2009 to present) HDRP-2010-36, Human Development Report Office (HDRO), United Nations Development Programme (UNDP), November 2010.

[37] Dani Rodrik. Has Globalization Gone Too Far? Number 57 in Peterson Institute Press: All Books. Peterson Institute for International Economics, April 1997. 
[38] Robert M. Solow. A skeptical note on the constancy of relative shares. The American Economic Review, 48(4):618-631, 1958.

[39] Katharina Trapp. Measuring the Labour Income Share of Developing Countries : Learning From Social Accounting Matrices. Technical report, 2015. 